\title{
Phenolic compounds from the lichen Parmotrema tinctorum
}

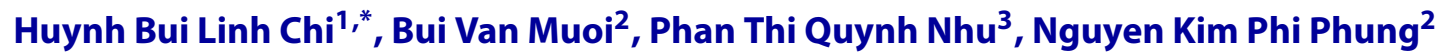

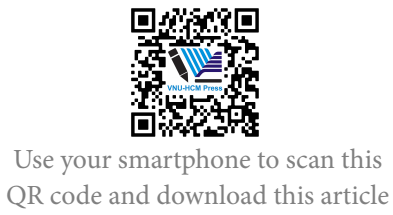

${ }^{1}$ Department of Science, Dong Nai University, Dong Nai Province

${ }^{2}$ Department of Organic Chemistry, University of Science, National University - Ho Chi Minh City, Ho Chi Minh City

${ }^{3}$ Faculty of Environmental Science, Sai Gon University, Ho Chi Minh City

\section{Correspondence}

Huynh Bui Linh Chi, Department of Science, Dong Nai University, Dong Nai Province

Email: hainhanchi@yahoo.com.vn

\section{History}

- Received: 2020-11-12

- Accepted: 2021-02-16

- Published: 2021-02-25

DOI : 10.32508/stdj.v24i1.2490

\section{Check for updates}

\section{Copyright}

(c) VNU-HCM Press. This is an openaccess article distributed under the terms of the Creative Commons Attribution 4.0 International license.

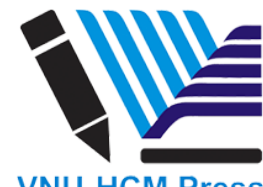

\begin{abstract}
Introduction: The metabolites of lichens concentrated depsidones, depsides, and diphenyl ethers were possessed antibiotic, antifungal, antiviral, antitumor, and anticancer activities. Parmotrema tinctorum (Despr. ex Nyl.) Hale, a species of foliose lichen, is widely distributed in Lam Dong province, Vietnam. Herein, this paper describes the isolation and structure elucidation of seven compounds isolated from this lichen. Methods: Phytochemical investigations of the ethyl acetate extract of the lichen P. tinctorum led to the isolation of seven pure compounds. Their chemical structures were elucidated by extensive HR-ESI-MS and NMR spectroscopic analysis and comparison with previously published data. Results: Seven compounds, namely orcinol (1), orsellinic acid (2), methyl orsellinate (3), methyl heamatomate (4), lecanorin (5), lecanoric acid (6), and gyrophoric acid (7). These compounds were determined the $\boldsymbol{\alpha}$-glucosidase inhibitory activity. Conclusions: Compound $\mathbf{7}$ was determined for the first time in P. tinctorum, and this was also the first time these compounds were determined the $\boldsymbol{\alpha}$-glucosidase inhibitory activity.

Key words: Parmotrema tinctorum (Despr. ex Nyl.) Hale, depside, phenolic, $\alpha$-glucosidase
\end{abstract}

\section{INTRODUCTION}

The development of an $\alpha$-glucosidase inhibitor derived from natural products is an important contribution to the treatment of diabetes. ${ }^{1,2}$ Parmotrema tinctorum was used as an edible spice for flavoring food in Kerela, India. ${ }^{3}$ The methanolic extract of $P$. tinctorum exhibited the anti-arthritic potential on experimental rats. ${ }^{4}$ For the purpose of searching for new classes of $\alpha$-glucosidase inhibitors, we reported the isolation and structural elucidation of seven compounds from the ethyl acetate extract of the lichen Parmotrema tinctorum (Nyl.) Hale and the $\alpha$-glucosidase inhibitory activity of these compounds.

\section{MATERIALS AND METHODS}

\section{General experimental procedures}

The HR-ESI-MS was recorded on a HR-ESI-MS MicrOTOF-Q mass spectrometer. The ${ }^{1} \mathrm{H}-\mathrm{NMR}$ $500(\mathrm{MHz})$ and ${ }^{13} \mathrm{C}-\mathrm{NMR}(125 \mathrm{MHz})$ spectra were recorded on a Bruker Avance 500 spectrometer. Thinlayer chromatography (TLC) was carried out on precoated silica gel 60 F254 or silica gel 60 RP-18 F254S (Merck), and the isolated compounds were visualized by spraying with $10 \% \mathrm{H}_{2} \mathrm{SO}_{4}$ solution followed by heating. Gravity column chromatography was performed on silica gel $60(0.040-0.063 \mathrm{~mm}$. Himedia).

\section{Plant material}

The thalli of the lichen Parmotrma tinctorum (Nyl.) Hale was collected at Lam Dong province, Vietnam, in April 2020 and authenticated by Dr. Vo Thi Phi Giao, Faculty of Biology, University of Science, National University - Ho Chi Minh city. A voucher specimen (No US-B025) was deposited in the Faculty of Chemistry, University of Science, National University - Ho Chi Minh City.

\section{Extraction and isolation}

The powder of the lichen P.tinctorum $(3.15 \mathrm{~kg}$ ) was exhaustively extracted with acetone at room temperature. After filtrated, the acetone solution was evaporated at the reduced pressure to provide the crude acetone extract (350.0 g), which was subjected to silica gel solid phase extraction and eluted consecutively with the solvents with various polar to afford $n$-hexane extract $(\mathrm{H}, 19.05 \mathrm{~g})$, chloroform extract (C, $119.72 \mathrm{~g})$, ethyl acetate extract (EA, $164.58 \mathrm{~g}$ ) and methanol extract $(\mathrm{M}, 31.08 \mathrm{~g})$.

The extract EA (164.58 g) was applied to silica gel column chromatography and eluted with the solvent systems of $n$-hexane-ethyl acetate (stepwise, 7:3, $5: 5,0: 10)$ then methanol to give 9 fractions, coded M1-M10. Fraction M1 (606.8 mg) was divided into two sub-fractions M1.1 (284.6 mg) and M1.2 (284.6 $\mathrm{mg}$ ), by silica gel column chromatography, using the mobile phase as $n$-hexane-chloroform $(7: 3, \mathrm{v} / \mathrm{v})$. Sub-fraction M1.1 was rechromatographed by silica gel column chromatography, eluted with $n$-hexanechloroform $(7: 3, \mathrm{v} / \mathrm{v})$ to yield $\mathbf{1}(12.0 \mathrm{mg})$. The same procedure for subfraction M1.2 (487 mg) was 
conducted, eluting with $n$-hexane-chloroform (5:5, $\mathrm{v} / \mathrm{v})$ to obtain $2(14.3 \mathrm{mg}), 3(18.7 \mathrm{mg})$ and $4(10.3$ $\mathrm{mg}$ ). Fraction M2 (16.2 g) was subjected to silica gel column chromatography and eluted by chloroformmethanol $(98: 2,95: 5,9: 1)$ to give 5 (9.5 mg), 6 (17.4 $\mathrm{mg})$ and 7 (11.2 mg).

\section{$\alpha$-Glucosidase inhibition assay}

The $\alpha$-glucosidase inhibitory activity was evaluated on all compounds according to the method of $\mathrm{Kim}^{5}$. A reaction mixture containing $3 \mathrm{mM} p$ nitrophenyl- $\alpha$-D-glucopyranoside $(25 \mu \mathrm{L}), 0.2 \mathrm{U} / \mathrm{mL}$ $\alpha$-glucosidase $(25 \mu \mathrm{L})$ in $0.01 \mathrm{M}$ phosphate buffer $(\mathrm{pH}=7.0)$ and the sample solution $(625 \mu \mathrm{L})$ was incubated at $37^{\circ} \mathrm{C}$ for $30 \mathrm{~min}$ and stopped by adding $0.1 \mathrm{M}$ $\mathrm{Na}_{2} \mathrm{CO}_{3}(375 \mu \mathrm{L})$. Absorbances were recorded at 401 $\mathrm{nm}$. One unit of $\alpha$-glucosidase activity was defined as the amount of enzyme liberating $p$-nitrophenol (1.0 $\mu \mathrm{M})$ per min. Acarbose was used as the positive control.

\section{RESULTS}

The chemical investigation on the extract EA of the lichen P.tinctorum led to the isolation of seven compounds by the use of efficient separation techniques, including orcinol (1), orsellinic acid (2), methyl orsellinate (3), methyl heamatomate (4), lecanorin (5), lecanoric acid (6), and gyrophoric acid (7). Their ${ }^{13} \mathrm{C}$ NMR data were performed in Table 1, and the following data were ${ }^{1} \mathrm{H}-\mathrm{NMR}$ data.

- Orcinol (1): Colorless needles, mp $107^{\circ} \mathrm{C}$. HRESI-MS (positive mode) $\mathrm{m} / z 125.0602[\mathrm{M}+\mathrm{H}]^{+}$ (calcd. for $\mathrm{C}_{7} \mathrm{H}_{8} \mathrm{O}_{2}+\mathrm{H}$ 125.0603). The ${ }^{1} \mathrm{H}$ NMR data $\left(\mathrm{CDCl}_{3}, \delta\right.$ ppm, $J$ in Hertz): 6.23 $(2 \mathrm{H}, d, 1.5, \mathrm{H}-1$ and $\mathrm{H}-5), 6.17(1 \mathrm{H}, t, 2.0, \mathrm{H}-3)$, $5.09(2 \mathrm{H}, s,-\mathrm{OH})$ and $2.24\left(3 \mathrm{H}, s, 6-\mathrm{CH}_{3}\right)$. The ${ }^{13} \mathrm{C}-\mathrm{NMR}\left(\mathrm{CDCl}_{3}\right)$ was presented in Table 1.

- Orsellinic acid (2): Colorless needles, mp 184 ${ }^{o}$ C. HR-ESI-MS (negative mode) $\mathrm{m} / z$ 167.0346 $[\mathrm{M}-\mathrm{H}]^{-}$(calcd. for $\mathrm{C}_{8} \mathrm{H}_{8} \mathrm{O}_{4}-\mathrm{H}$ 167.0345). The ${ }^{1} \mathrm{H}-\mathrm{NMR}$ data (DMSO- $d_{6}, \delta \mathrm{ppm}, J$ in Hertz): $6.04(1 \mathrm{H}, d, 2.0, \mathrm{H}-5), 6.02(1 \mathrm{H}, d, 2.0, \mathrm{H}-3)$ and $2.41\left(3 \mathrm{H}, s, 6-\mathrm{CH}_{3}\right)$. The ${ }^{13} \mathrm{C}-\mathrm{NMR}$ (DMSO- $\left.d_{6}\right)$ was presented in Table 1.

- Methyl orsellinate (3): Colorless needles, mp. 143-144 ${ }^{\circ}$ C. HR-ESI-MS (positive mode) $\mathrm{m} / \mathrm{z}$ $183.0668[\mathrm{M}+\mathrm{H}]^{+}$(calcd. for $\mathrm{C}_{9} \mathrm{H}_{10} \mathrm{O}_{4}+\mathrm{H}$ 183.0658). The ${ }^{1} \mathrm{H}-\mathrm{NMR}$ data $\left(\mathrm{CDCl}_{3}, \delta \mathrm{ppm}\right.$, $J$ in Hertz): $11.77(1 \mathrm{H}, s, 2-\mathrm{OH}), 6.28(1 \mathrm{H}, d$, 2.5, H-3), $6.23(1 \mathrm{H}, d, 2.5, \mathrm{H}-5), 3.92(3 \mathrm{H}, s$, $\left.\mathrm{OCH}_{3}\right)$ and $2.48\left(3 \mathrm{H}, s, 6-\mathrm{CH}_{3}\right)$. The ${ }^{13} \mathrm{C}-\mathrm{NMR}$ $\left(\mathrm{CDCl}_{3}\right)$ was presented in Table 1.
- Methyl heamatomate (4): Colorless needles, mp $146{ }^{\circ} \mathrm{C}$. HR-ESI-MS (negative mode) $\mathrm{m} / \mathrm{z}$ $209.0449\left[^{[\mathrm{M}-\mathrm{H}]^{-}}\right.$(calcd. for $\mathrm{C}_{10} \mathrm{H}_{10} \mathrm{O}_{5}-\mathrm{H}$ 209.0450). The ${ }^{1} \mathrm{H}$-NMR data (Acetone- $d_{6}, \delta$ ppm, $J$ in Hertz): $12.84(1 \mathrm{H}, s, 2-\mathrm{OH}), 12.24$ $(1 \mathrm{H}, s, 4-\mathrm{OH}), 10.24(1 \mathrm{H}, \mathrm{,}-\mathrm{CHO}), 6.30(1 \mathrm{H}$, , $\mathrm{H}-5), 3.93\left(3 \mathrm{H},,-\mathrm{OCH}_{3}\right), 2.48\left(3 \mathrm{H}, s,-\mathrm{CH}_{3}\right)$. The ${ }^{13} \mathrm{C}-\mathrm{NMR}$ (Acetone- $d_{6}$ ) was presented in Table 1.

- Lecanorin (5): White amorphous powder. HRESI-MS (negative mode) $\mathrm{m} / z$ 273.0773 [M-H] ${ }^{-}$ (calcd. for $\mathrm{C}_{15} \mathrm{H}_{14} \mathrm{O}_{5}-\mathrm{H}$ 273.0763). The ${ }^{1} \mathrm{H}$ NMR data $\left(\mathrm{CDCl}_{3}, \delta\right.$ ppm, $J$ in Hertz): 11.42 $(1 \mathrm{H}, s, 2-\mathrm{OH}), 6.59(1 \mathrm{H}, s, \mathrm{H}-5), 6.58(1 \mathrm{H}, s$, H-1'), 6.50 (1H, $\left.s, \mathrm{H}-3^{\prime}\right), 6.32$ (1H, $\left.s, \mathrm{H}-3\right), 6.31$ $(1 \mathrm{H}, s, \mathrm{H}-5), 2.62\left(3 \mathrm{H}, s, 6-\mathrm{CH}_{3}\right)$ and $2.33(3 \mathrm{H}, s$, $\left.{ }^{\prime}{ }^{\prime}-\mathrm{CH}_{3}\right)$. The ${ }^{13} \mathrm{C}-\mathrm{NMR}\left(\mathrm{CDCl}_{3}\right)$ was presented in Table 1.

- Lecanoric acid (6): Colorless needles, mp. 184 ${ }^{o} \mathrm{C}$. HR-ESI-MS (negative mode) $\mathrm{m} / z 317.0663$ $[\mathrm{M}-\mathrm{H}]^{-}$(calcd. for $\mathrm{C}_{16} \mathrm{H}_{14} \mathrm{O}_{7}-\mathrm{H}$ 317.0662). The ${ }^{1} \mathrm{H}$-NMR data (Acetone- $d_{6}, \delta \mathrm{ppm}, J$ in Hertz): $11.13(1 \mathrm{H}, s, 2-\mathrm{OH}), 6.77(1 \mathrm{H}, s, \mathrm{H}-3)$, $6.74(1 \mathrm{H}, s, \mathrm{H}-5), 6.39(1 \mathrm{H}, s, \mathrm{H}-5$ '), $6.30(1 \mathrm{H}$, $s, \mathrm{H}-3$ ') $2.63\left(3 \mathrm{H}, s, 6-\mathrm{CH}_{3}\right)$ and $2.59(3 \mathrm{H}, s$, ${ }^{6}-\mathrm{CH}_{3}$ ). The ${ }^{13} \mathrm{C}-\mathrm{NMR}$ (Acetone- $d_{6}$ ) was presented in Table 1.

- Gyrophoric acid (7): Colorless needles, mp. 225 ${ }^{o}$ C.. HR-ESI-MS (negative mode) $\mathrm{m} / z 467.0989$ [M-H] ${ }^{-}$(calcd. for $\mathrm{C}_{24} \mathrm{H}_{20} \mathrm{O}_{10}-\mathrm{H}$ 467.0978). The ${ }^{1} \mathrm{H}$-NMR data (Acetone- $d_{6}, \delta \mathrm{ppm}, J$ in Hertz): 11.13 (1H, $s, 2-\mathrm{OH}), 6.87$ (1H, $\left.s, \mathrm{H}-3^{\prime}\right)$, $6.87\left(1 \mathrm{H}, s, \mathrm{H}-3^{\prime}\right), 6.80(1 \mathrm{H}, s, \mathrm{H}-3), 6.76(1 \mathrm{H}, s$, H-5), 6.85 (1H, $\left.s, \mathrm{H}-5^{\prime}\right), 6.39$ (1H, $s, \mathrm{H}-5$ '), 6.31 $\left(1 \mathrm{H}, s, \mathrm{H}-3\right.$ ”) $2.66\left(3 \mathrm{H}, s, 6^{\prime}-\mathrm{CH}_{3}\right), 2.65(3 \mathrm{H}$, $\left.s, 6-\mathrm{CH}_{3}\right)$ and $2.61\left(3 \mathrm{H}, s, 6\right.$ " $\left.-\mathrm{CH}_{3}\right)$. The ${ }^{13} \mathrm{C}$ NMR (Acetone- $d_{6}$ ) was presented in Table 1.

\section{DISCUSSION}

Compound 1 was isolated as colorless needles; its molecular formula was determined as $\mathrm{C}_{7} \mathrm{H}_{8} \mathrm{O}_{2}$ through its pseudo molecular ion peak at $\mathrm{m} / \mathrm{z}$ $125.0602[\mathrm{M}+\mathrm{H}]^{+}$in the HR-ESI-MS spectrum. The ${ }^{1} \mathrm{H}-\mathrm{NMR}$ spectrum data of compound 1 gave signals of one methyl group at $\delta_{H} 2.24(3 \mathrm{H}, s)$, two hydroxyl protons at $\delta_{H} 5.09(2 \mathrm{H}, s,-\mathrm{OH})$ and three aromatic methine protons at $\delta_{H} 6.23(2 \mathrm{H}, d, 1.5)$ and $6.17(1 \mathrm{H}$, $t, 2.0)$.The ${ }^{13} \mathrm{C}-\mathrm{NMR}$ spectrum data showed the resonances of five signals, including one methyl group at $\delta_{C} 21.5(\mathrm{C}-7)$ and four aromatic methine carbons at $\delta_{C} 100.1,108.9,141.1$ and 156.8 (Table 1). The HMBC spectrum showed the correlations of proton 
H-3 with two oxygenated carbons C-2 and C-4, of methyl proton H-6 with carbons C-1, C-5, and C-6, and of proton $\mathrm{H}-1$ and $\mathrm{H}-5$ with carbons $\mathrm{C}-6$. The good compatibility of its NMR data with those of orcinol in the literature ${ }^{6}$ proposed that compound $\mathbf{1}$ was orcinol.

Compound 2 was obtained as colorless needles. The spectral features of $\mathbf{2}$ were closely similar to those of 1 , except for the absence of one aromatic proton and the presence of carboxyl group in 2 . The position of the carboxyl group was determined via HMBC correlations from the methyl protons at $\delta_{H} 2.41(\mathrm{H}-8)$ to carbon signals C-1 $\left(\delta_{C} 109.4\right), \mathrm{C}-5\left(\delta_{C} 100.3\right)$, and C-6 $\left(\delta_{C} 142.5\right)$ and from the aromatic proton at $\delta_{H}$ $6.02(\mathrm{H}-3)$ to carbon signals C-1 $\left(\delta_{C} 109.4\right), \mathrm{C}-2\left(\delta_{C}\right.$ $160.4)$ and C-4 $\left(\delta_{C} 165.3\right)$ (Figure 1). The NMR data of $\mathbf{2}$ showed good compatibility with those of orselinic acid in the literature ${ }^{6,7}$, so the structure of compound 2 was suggested as orselinic acid.

The comparison NMR data of $\mathbf{2}$ and $\mathbf{3}$ showed that the latter possessed one more methoxy group. This was evidenced by the presence of a signal of methoxy protons adjacent to a carboxyl group at $\delta_{H} 3.92$ (H-9). Furthermore, the molecular weight of compound 3 is 14 mass units larger than that of compound 2, which could be attributed to a methoxy group in 3 . Base on the above NMR data analysis as well as the HR-ESIMS spectrum of $\mathbf{3}$, the chemical structure of $\mathbf{3}$ was determined as methyl orselinate. ${ }^{8}$

The comparison of chemical shift values of 4 with corresponding ones of $\mathbf{3}$ also showed that they had the same structure. The difference was that an aromatic proton at C-3 in $\mathbf{3}$ was replaced by a formyl group in 4. This was evident by the absence of an aromatic proton and the observation of a formyl proton signal and a carbonyl carbon signal in the low field zone at $\delta_{H}$ $/ \delta_{C} 10.24 / 194.8$. The position of this formyl group was clarified on the basis of the HMBC correlation between the formyl proton $(\mathrm{H}-8)$ to $\mathrm{C}-2\left(\delta_{C} 168.5\right)$ and C-3 $\left(\delta_{C} 109.1\right)$. It corresponded to the molecular formula $\mathrm{C}_{10} \mathrm{H}_{10} \mathrm{O}_{5}$, which was determined through its pseudo molecular ion peak at $m / z 209.0449[\mathrm{M}-\mathrm{H}]^{-}$. By comparing these data with those published in the literature, ${ }^{8} 4$ was identified as methyl heamatomate. Compound 5 was a depside. Its molecular formula was determined as $\mathrm{C}_{15} \mathrm{H}_{14} \mathrm{O}_{5}$ through its pseudo molecular ion peak at $m / z 273.0773[\mathrm{M}-\mathrm{H}]^{-}$(calcd. for $\mathrm{C}_{15} \mathrm{H}_{14} \mathrm{O}_{5}-\mathrm{H}$ 273.0763). The ${ }^{1} \mathrm{H}-\mathrm{NMR}$ spectrum data of compound $\mathbf{5}$ displayed signals of a chelated hydroxyl group at $\delta_{H} 11.42(1 \mathrm{H}, s)$, five aromatic protons at $\delta_{H} 6.59,6.58,6.50,6.32$ and $6.31(1 \mathrm{H}$ each, $s$ ), and two methoxyl groups at $\delta_{H} 2.62$ and
$2.33(3 \mathrm{H}$ each, $s)$. The ${ }^{13} \mathrm{C}-\mathrm{NMR}$ exhibited 15 carbon signals, consisting of two methyl carbon signals $\left(\delta_{C} 21.6\right.$ and 24.7$)$, twelve aromatic carbons $\left(\delta_{C} 101-\right.$ $167 \mathrm{ppm})$, and one carboxyl carbon signals $\left(\delta_{C} 170.5\right)$ (Table 1). Base on the above HR-ESI-MS analysis as well as 2D NMR data of $\mathbf{5}$ showed that it could be a depside that was combined by $\mathbf{2}$ and $\mathbf{1}$ through an ester bridge (Figure 1). Thus compound $\mathbf{5}$ was assigned as lecanorin $^{7,9}$.

Compound 6 was also a depside with similar NMR signals as those of $\mathbf{5}$, except for the displaying of carboxyl group at C-1 instead of an aromatic proton in 5. The mass value of compound 6 has 44 more atomic mass units than those of $\mathbf{5}$, which showed the presence of a carboxyl group. Base on the good compatibility of its HR-ESI-MS and NMR data with those reported in the literature ${ }^{7,9}, 6$ was proposed to be lecanoric acid. Compound 7 was a depside. The NMR data of compound 7 displayed signals of three orselinic units with six aromatic protons, three methyl groups in ${ }^{1} \mathrm{H}$ NMR spectrum and 24 carbon signals in ${ }^{13} \mathrm{C}-\mathrm{NMR}$ spectrum (Table1). Furthermore, the HR-ESI-MS spectrum of compound 7 showed a pseudomolecular ion peak at $m / z 467.0989[\mathrm{M}-\mathrm{H}]^{-}$calcd. for $\mathrm{C}_{24} \mathrm{H}_{20} \mathrm{O}_{10}-\mathrm{H} 467.0978$, therefore 7 was indicated as gyrophoric acid. ${ }^{9}$

The inhibitory effect against $\alpha$-glucosidase of some isolated compounds of P.tinctorum was tested. The results of tested compounds 4 displayed high-potency inhibitors with IC50 values in $38.9 \mu \mathrm{M}$, compared with the control acarbose IC50 $214.5 \mu \mathrm{M}$. The pioneered results of evaluating the inhibitory effect against $\alpha$-glucosidase were also presented in Table 2 .

\section{CONCLUSION}

From the extract EA of the lichen Parmotrema tinctorum collected in Di Linh district, Lam Dong province, using various chromatographic methods, seven phenolic compounds were isolated. Their structures were determined as orcinol (1), orsellinic acid (2), methyl orsellinate (3), methyl heamatomate (4), lecanorin (5), lecanoric acid (6), and gyrophoric acid (7). Among them, compounds 7 were reported for the first time in such species. This was the first time these compounds were determined the $\alpha$-glucosidase inhibitory activity. This is remarkable for our further research.

\section{ABBREVIATIONS}

HR-ESI-MS: High resolution- Electrospray ionization-Mass spectrometry

${ }^{1}$ H NMR: Proton nuclear magnetic resonance

13 C NMR: Carbon-13 nuclear magnetic resonance 
Table 1: ${ }^{1}$ C-NMR data of compound 1-7

\begin{tabular}{|c|c|c|c|c|c|c|c|}
\hline No & $\mathbf{1}^{(a)}$ & $2^{(b)}$ & $3^{(a)}$ & $4^{(c)}$ & $5^{(a)}$ & $6^{(c)}$ & $7^{(c)}$ \\
\hline 1 & 108.9 & 109.4 & 105.7 & 105.4 & 105.0 & 111.6 & 112.4 \\
\hline 2 & 156.8 & 160.4 & 165.4 & 168.5 & 166.2 & 165.4 & 165.5 \\
\hline 3 & 100.1 & 100.3 & 101.4 & 109.1 & 101.6 & 109.4 & 109.2 \\
\hline 4 & 156.8 & 165.3 & 160.7 & 167.1 & 161.4 & 155.0 & 154.8 \\
\hline 5 & 108.9 & 100.3 & 111.6 & 112.4 & 112.0 & 117.2 & 116.9 \\
\hline 6 & 141.1 & 142.5 & 144.1 & 153.4 & 150.0 & 144.8 & 144.8 \\
\hline 7 & 21.5 & 173.0 & 172.3 & 172.6 & 170.5 & 170.4 & 169.0 \\
\hline 8 & & 23.4 & 24.4 & 194.8 & 24.7 & 23.9 & 23.9 \\
\hline 9 & & & 52.0 & 24.9 & & & \\
\hline 10 & & & & 52.9 & & & \\
\hline 1' & & & & & 114.8 & 104.5 & 113.5 \\
\hline $2^{\prime}$ & & & & & 150.8 & 166.8 & 163.0 \\
\hline 3' & & & & & 106.0 & 101.9 & 109.5 \\
\hline $4^{\prime}$ & & & & & 156.6 & 164.3 & 155.0 \\
\hline $5^{\prime}$ & & & & & 114.4 & 112.9 & 117.5 \\
\hline $6^{\prime}$ & & & & & 141.1 & 144.6 & 143.2 \\
\hline 7' & & & & & 21.6 & 174.0 & 169.0 \\
\hline 8' & & & & & & 24.4 & 22.9 \\
\hline 1" & & & & & & & 104.8 \\
\hline 2" & & & & & & & 166.8 \\
\hline 3" & & & & & & & 101.9 \\
\hline 4” & & & & & & & 164.3 \\
\hline 5” & & & & & & & 113.0 \\
\hline 6" & & & & & & & 144.8 \\
\hline 7" & & & & & & & 170.4 \\
\hline 8” & & & & & & & 24.4 \\
\hline
\end{tabular}

(a) $\mathrm{CDCl}_{3} ;$ (b) DMSO- $_{6} ;$ (c) Acetone- $d_{6}$

Table 2: $\alpha$-Glucosidase inhibitory effects of some isolated compounds

\begin{tabular}{lll}
\hline No & Compound & IC $_{50}{ }^{a}(\mu \mathbf{M}) \pm \mathbf{S D}$ \\
1 & Orcinol & $>250$ \\
2 & Orselinic acid & $>250$ \\
3 & Methyl orselinate & $>250$ \\
4 & Methyl heamatomate & 38,9 \\
5 & Lecanorin & $>250$ \\
6 & Lecanoric acid & $>250$ \\
7 & Acarbose & $\mathbf{2 1 4 . 5}$ \\
\hline
\end{tabular}



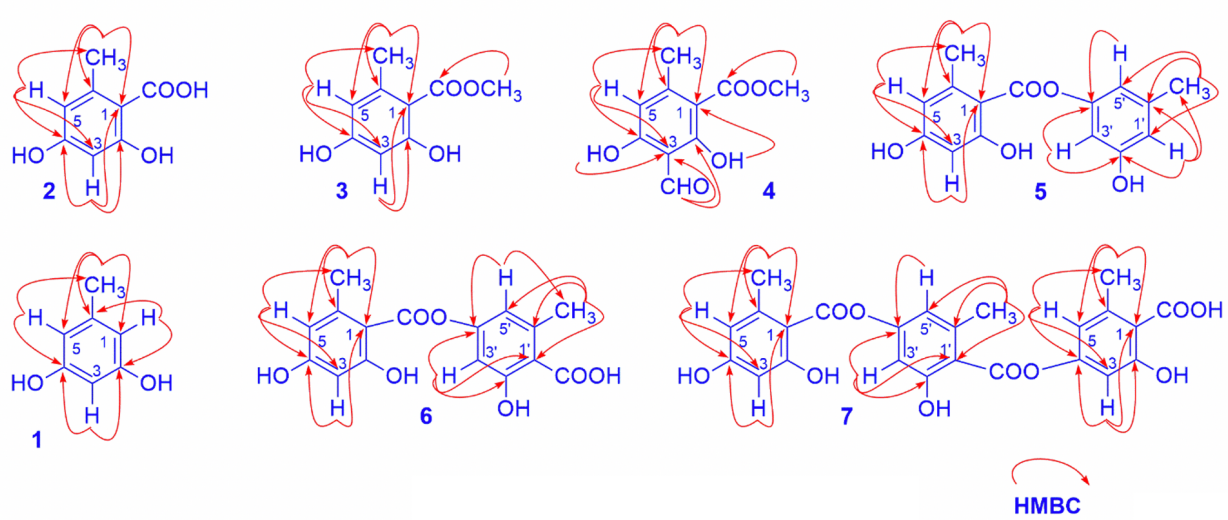

Figure 1: Key HMBC of isolated compounds

HMBC: Heteronuclear multiple bond correlation $s$ : singlet

$d$ : doublet

\section{COMPETING INTEREST}

The authors declare no competing financial interest.

\section{AUTHORS' CONTRIBUTION}

Huynh B.L.C has contributed in conducting experiments, acquisition of data, interpretation of data. Bui V.M, Phan T.Q.N interpreted NMR and MS data as well as searched the bibliography Nguyen K. P. P. gave final approval of the manuscript to be submitted.

Corresponding author: Dr. Huynh Bui Linh Chi, Dong Nai University, 03 Le Quy Don, Tan Hiep district, Bien Hoa city, Dong Nai province. Email : hainhanchi@yahoo.com.vn.

\section{ACKNOWLEDGMENT}

We would like to thank Dr. Vo Thi Phi Giao for lichen identification.

\section{REFERENCES}

1. Funke M, Melzig F. Traditionally used plants in diabetes therapy-phytotherapeutics as inhibitors of $\alpha$-amylase activity.
Revista Brasileira de Farmacognosia. 2006;16:1-5. Available from: https://doi.org/10.1590/S0102-695X2006000100002.

2. Choi CW, et al. Yeast $\alpha$-Glucosidase inhibition by isoflavones from plants of Leguminosae as an in vitro alternative to acarbose. Journal of Agricultural and Food Chemistry. 2010;58:9988-9993. PMID: 20734984. Available from: https://doi.org/10.1021/jf101926j.

3. Anupama TV, et al. Phytochemical screening and proximate composition of lichen Parmotrema tinctorum (Nyl.) Hale (Parmeliaceae) from Wayanad, Kerala. International Journal of Chemical Studies. 2017;5:1003-1007.

4. Nash-III TH. Lichen biology, 2nd Ed. Cambridge Univ. Press. Cambridge. New York. 2008;47.

5. Kim KY, et al. Potent $\alpha$-glucosidase inhibitors purified from the red alga Grateloupia elliptica. Phytochemistry. 2008;69:28202825. PMID: 18951591. Available from: https://doi.org/10.1016/ j.phytochem.2008.09.007.

6. Huneck S, Yoshimura I. Identification of lichen substances. Springer. New York. 1996;Available from: https://doi.org/10. 1007/978-3-642-85243-5.

7. Choudhary Ml, et al. New antiglycation and enzyme inhibitors from Parmotrema cooperi. Science China Chemistry. 2011;54:1926-1931. Available from: https://doi.org/10.1007/ s11426-011-4436-2.

8. Duong TH. A new monoaromatic compound from the lichen Parmotrema tsavoense (Krog\&Swinscow) Krog\&Swinscow (Parmeliaceae). Journal of Science-HCM City University Education. 2017;14:12-17.

9. Duong TH. Phenolic compounds from Pamotrema dilatatum growing in Lam Dong province. Science\&Technology Develpoment Journal. 2019;22:114-119. Available from: https://doi.org/ 10.32508/stdj.v22i1.1010. 